\title{
Expression and localization of prostaglandin receptors and stromal factors in human cervix - Variations in pregnant and non-pregnant states
}

\author{
Chellakkan S. Blesson $^{1 * \#}$, Nathalie Roos ${ }^{1,2 \#}$, Olof Stephansson ${ }^{2,3}$, Britt Masironi ${ }^{1}$, Susann Reinert ${ }^{1}$, \\ Ylva Vladic Stjernholm ${ }^{2}$, Gunvor Ekman-Ordeberg ${ }^{2}$, Lena Sahlin ${ }^{1}$ \\ ${ }^{1}$ Division for Reproductive Endocrinology and the Pediatric Endocrinology Unit, Department of Women's and Children's Health, \\ Karolinska University Hospital-Solna, Karolinska Institutet, Stockholm, Sweden \\ ${ }^{2}$ Division of Obstetrics and Gynecology, Department of Women's and Children's Health, Karolinska University Hospital-Solna, \\ Karolinska Institutet, Stockholm, Sweden \\ ${ }^{3}$ Clinical Epidemiology Unit, Department of Medicine, Karolinska Institutet, Stockholm, Sweden \\ Email: ${ }^{*}$ selvanes@bcm.edu
}

Received 10 September 2013; revised 10 October 2013; accepted 17 October 2013

Copyright (C) 2013 Chellakkan S. Blesson et al. This is an open access article distributed under the Creative Commons Attribution License, which permits unrestricted use, distribution, and reproduction in any medium, provided the original work is properly cited.

\begin{abstract}
Prostaglandins (PGs) mediate cervical ripening leading to parturition. PGs are used successfully to induce cervical ripening. However, the cell type specific expression of $P G$ receptor subtypes and various stromal factors important for cervical ripening in human cervix is not known. Our objective was to investigate the expression and localization of PG receptors EP1-4 and FP and localization of stromal factors CTGF (connective tissue growth factor), furin, calgranulin B, ALOX12 (arachidonate 12-lipooxy-genase) and ALOX15 in human cervical tissue from pregnant and non-pregnant women. Cervical biopsies were obtained from non-pregnant (NP), term pregnant (TP) and post-partum (PP) women. The mRNA expression was determined with real-time PCR, protein expression and localization with immunohistochemistry. Our results show that the EP2 mRNA level was higher in the PP group as compared to TP, whereas the EP4 mRNA level was lower in the TP group as compared to NP. Concomitantly stromal EP2 and epithelial EP3 immunoreactivity was higher in the TP as compared to the NP group, while the EP4 immunostaining in glands was lower in the TP as compared to the PP group. Immunostaining of endothelial CTGF, smooth muscle furin and ALOX12, were all lower in the TP group as compared to NP, for CTGF also the PP group was lower than NP. Endothelial calgranulin B
\end{abstract}

\footnotetext{
${ }^{*}$ Corresponding author.

Present address: Department of Obstetrics and Gynecology, Baylor College of Medicine, Houston, Texas 77030, USA.

${ }^{\#} \mathrm{CSB}$ and NR contributed equally to the study.
}

immunoreactivity was higher in the $\mathrm{PP}$ group than the NP group. PG receptors and stromal factors exhibit differential expression in the cervix from women in non-pregnant and pregnant states, implying their involvement in the process of cervical ripening.

Keywords: Cervical Ripening; Pregnancy; Extracellular Matrix; Prostaglandin Receptors

\section{INTRODUCTION}

Prostaglandins (PGs) are key pro-inflammatory agents that mediate cervical ripening [1]. Cervical ripening is an inflammation-like process, involving the invasion of leukocytes, which facilitates the softening, dilation and effacement of the cervix [2]. Further support for the inflammation-like model of cervical ripening is given by the elevated level of IL-8 and the rise in leukocyte count at the time of labor $[2,3]$. Invasion of leukocytes, along with the inflammation mediated remodeling process of the extracellular matrix (ECM), is crucial for normal parturition [2].

PGs are widely used to induce cervical ripening, for labor induction and for termination of pregnancy causing both cervical ripening and uterine contractions $[4,5]$. However, the cell type specific expression of the different $P G$ receptors in human cervix is not known. PGs act via their receptors and perform various functions in their target tissues depending on the type of receptor activated. PG receptors are G-protein coupled receptors mediating smooth muscle cell contractility and relaxation through different signaling pathways [6]. Contractility in smooth 
muscle cells is mediated by EP1, EP3 and FP, whereas EP2 and EP4 mediate relaxation in uterus and smooth muscle cells of vessels [7]. PGE2 is the natural ligand for the PG receptor subtypes EP1-4 whereas PGF2 $\alpha$ is the ligand for FP [7].

The expression of PG receptors and the mechanisms by which PGs act on the cervix are relatively well described in animal studies [8-10]. However, available human studies are few and the understanding of PG receptor expression and their regulation in human cervix is poorly understood.

Apart from the PG receptors, several stromal factors are also involved in various aspects of cervical ripening. Connective tissue growth factor (CTGF) is involved in the regulation of ECM production, tissue remodeling, cell migration and differentiation [11]. Calgranulin B is a calcium binding protein expressed mainly in neutrophils and highly expressed in inflammatory sites [12]. It is also involved in ECM remodeling and acts as a substrate for matrix metalloproteinase (MMP)-2 and MMP-9 [13]. Calgranulin $\mathrm{B}$ is an important factor during parturition exhibiting increased mRNA levels in the uterus and cervix of women in labor [14]. Furin is another essential factor regulating the inflammatory response by catalyzing the activation of a variety of proteins such as MMPs [15] and hence a possible mediator in cervical ripening.

Arachidonate 12-lipoxygenase (ALOX12) and arachidonate 15-lipoxygenase (ALOX15) are oxidoreductases involved in arachidonate metabolism [16]. ALOX12 has been described in human cervix [17], and in uterus from baboons during pregnancy and labor [18]. ALOX15 has also been detected in human myometrium during pregnancy with a lower expression at term and in labor [19]. ALOX12 and ALOX15 are mediators of inflammation and thus possible participants in the parturition process [20].

In order to understand the role of PG receptors and stromal factors in human cervix we investigated their expression and localization. We hypothesized that ex- pression of cervical PG receptors and stromal factor proteins differ in term pregnant, post-partum and non-pregnant women.

\section{MATERIALS AND METHODS}

\subsection{Patients}

All women included in this study were Caucasian, healthy and non-smokers. A summary of their clinical characteristics is presented in Table 1. All pregnant women had uncomplicated pregnancies and were not taking any regular medication prior to parturition. Gestational length was estimated with second trimester routine ultrasound dating. Women in the term pregnant (TP) group $(\mathrm{n}=12)$ had unripe cervices with a Bishop Score $\leq 5$ points and none of them were in labor. They had a mean age $( \pm \mathrm{SD})$ of $33.2 \pm 3.8$ years, and a median gestational length of $38+3$ (38 completed gestational weeks and three days) (range $37+2$ to $39+6$ ) weeks. All women in this group were primiparous, except for four women who had undergone one previous caesarean section. The women in the post-partum (PP) group $(n=15)$ were all at term and primiparous. They had a mean age of $30.3 \pm 4.8$ years, and a median gestational age of $39+$ 6 (range $39+1$ to $41+6$ ) weeks (Table 1). The nonpregnant (NP) group consisted of women who were undergoing hysterectomy due to benign uterine disorders not affecting the cervix and without any cervical pathology. They were all healthy and menstruated regularly. This group $(\mathrm{n}=8)$ had a mean age of $43.4 \pm 5.5$ years, and a median parity of II (range I-III) (Table 1). The study was approved by the Local Ethics Committee at Karolinska Institutet, Stockholm, Sweden. Informed consent was obtained from all women before biopsies were collected.

\subsection{Tissue Collection}

Cervical biopsies were obtained and tissues handled as described in a previous publication by our group [21].

Table 1. Summary table showing clinical characteristics of the women included in the study.

\begin{tabular}{|c|c|c|c|}
\hline & Term pregnant & Post-partum & Non pregnant \\
\hline$n$ & 12 & 15 & 8 \\
\hline Gestational length ${ }^{\mathrm{a}}$ median (range) & $38+3(37+2$ to $39+6)$ & $39+6(39+1 \text { to } 41+6)^{b}$ & - \\
\hline Maternal age (years) & $33.2 \pm 3.8(28$ to 38$)$ & $30.3 \pm 4.8(22$ to 37$)$ & $43.4 \pm 5.5^{\mathrm{c}}$ \\
\hline $\mathbf{B M I}^{\mathrm{d}}$ & $23.8 \pm 3.6(18.9$ to 29.8$)$ & $21.7 \pm 2.8(16.9$ to 26.8$)$ & Missing \\
\hline Women receiving oxytocin & 0 & 11 & - \\
\hline
\end{tabular}

Note: Means with $\left( \pm\right.$ ) standard deviations and (range) are presented unless otherwise stated. ${ }^{\mathrm{a}}$ Completed gestational weeks and days; ${ }^{\mathrm{b}}$ Significantly different compared to TP; ${ }^{\mathrm{c}}$ Significantly different compared to TP and PP groups; ${ }^{\mathrm{d}}$ Weight and length recorded at the first antenatal visit presented as Body Mass Index (BMI) $\left(\mathrm{kg} / \mathrm{m}^{2}\right)$. 
Briefly, cervical biopsies were obtained trans-vaginally from the anterior cervical lip (12 o'clock position) at 10 $20 \mathrm{~mm}$ depth. Cervical biopsies were taken immediately after hysterectomies for the NP group; during elective caesarean section before the onset of labor for the TP group and immediately after parturition for the PP group. When possible, a small piece was cut off prior to fixation, and frozen in $-70^{\circ} \mathrm{C}$ for RNA preparation. When the biopsy was too small to be divided, it was fixed and embedded in paraffin. We could not obtain large enough biopsies for both paraffin embedding and RNA preparation from all women. In some cases, the quantity of RNA was not enough to perform all the experiments. Therefore the $n$ values of each specific analysis differ from the total $n$. The exact $n$ values are given in the corresponding legends to figures. Consequently, some groups did not have sufficient numbers. We still decided to show the results, since obtaining cervical biopsies are difficult, but the conclusions have to be interpreted cautiously.

\subsection{RNA Isolation and qPCR Analysis}

Total RNA from frozen cervical tissue samples was purified with the RNeasy ${ }^{\circledR}$ Mini kit (Qiagen GmbH, Hilden, Germany) according to a procedure for RNA isolation from fibrous tissues, including a DNase step, as recommended by the manufacturer and described before [22], with the difference that the final volume was $30 \mu \mathrm{L}$ in the present study. The oligonucleotide primers for EP1, EP2, EP3, EP4, FP and cyclophilin A are presented in Table 2, as well as their predicted sizes. Real time PCR (polymerase chain reaction) was performed in an iCycler ${ }^{\mathrm{TM}} \mathrm{iQ}$ Real Time PCR System (Bio-Rad Laboratories, Inc). For PCR, the cDNAs corresponding to 66 or $100 \mathrm{ng}$ RNA (Table 2) were added to $12.5 \mu \mathrm{L}$ of $\mathrm{iQ}^{\mathrm{TM}} \mathrm{SYBR}{ }^{\mathrm{T}}$ Green Supermix (Bio-Rad) and $0.3 \mu \mathrm{M}$ of each oligonucleotide primer in a final volume of $25 \mu \mathrm{L}$. After initial incuba- tion for 3 minutes at $95^{\circ} \mathrm{C}$, the samples were subjected to 40 cycles of 10 seconds at $95^{\circ} \mathrm{C}$ followed by 45 seconds at $56^{\circ} \mathrm{C}$ or $59^{\circ} \mathrm{C}$ (Table 2). All PCR assays were performed in replicates twice and their purity was confirmed by a melting curve analysis. Further, the PCR products were checked on agarose gels and all exhibited single bands of the expected sizes. Each PCR assay included a negative control containing an RNA sample without reverse transcription. The primer pairs (Table 2) were designed with the NCBI/Primer-BLAST program using human gene sequences. Cyclophilin A was used as the housekeeping gene. Several genes were tested and cyclophilin A was chosen since it showed no variation between groups. The PCR amplification rate and the cycle threshold $(\mathrm{Ct})$ values were analyzed using iCycler ${ }^{\mathrm{TM}}$ iQ 3.1 software (Bio-Rad). The values of relative expression of genes of interest were normalized against the cyclophilin A product. Due to the limited amount of samples, mRNA determinations were only performed for EP1-4 and FP.

\subsection{Immunohistochemistry}

Immunostaining was performed using the avidin-biotin peroxidase complex (ABC) method, as described previously for the EPs and FP [22]. The blocking, incubation conditions and antibody concentrations of PG receptors and stromal factors are as shown in Table 3. Manual scorings were performed independently by two observers blinded to the identity of the slides. The staining was evaluated semi-quantitatively using a grading system. The staining intensity and amount of positive cells were graded on a scale of: (0) no staining, (1) faint staining/few positive cells, (2) moderate staining/many positive cells and (3) strong staining/majority of cells positive. This scoring method has been used before by our group [22] and by others [23].

Table 2. Oligonucleotide primers used for real-time PCR.

\begin{tabular}{|c|c|c|c|c|c|c|}
\hline & Accession No. & Primers $F=$ forward $; R=$ reverse & Position & Product (bp) & cDNA & Annealing step \\
\hline EP1 (PTGER1) & NM_000955.2 & $\begin{array}{l}\text { F: TTGTCGGTATCATGGTGGTG } \\
\text { R: ATGTACACCCAAGGGTCCAG }\end{array}$ & $\begin{array}{l}\text { bp } 1014-1033 \\
\text { bp } 1173-1154\end{array}$ & 160 & $100 \mathrm{ng}$ & $59^{\circ} \mathrm{C} / 45 \mathrm{~s}$ \\
\hline EP2 (PTGER2) & NM_000956 & $\begin{array}{l}\text { F: CCACCTCATTCTCCTGGCTA } \\
\text { R: TTCCTTTCGGGAAGAGGTTT }\end{array}$ & $\begin{array}{l}\text { bp } 1034-1053 \\
\text { bp } 1133-1114\end{array}$ & 100 & $100 \mathrm{ng}$ & $59^{\circ} \mathrm{C} / 45 \mathrm{~s}$ \\
\hline EP3 (PTGER3) & NM_198718.1 & $\begin{array}{l}\text { F: AGCTTATGGGGATCATGTGC } \\
\text { R:TTTCTGCTTCTCCGTGTGTG }\end{array}$ & $\begin{array}{l}\text { bp } 1079-1098 \\
\text { bp } 12001181\end{array}$ & 122 & $100 \mathrm{ng}$ & $59^{\circ} \mathrm{C} / 45 \mathrm{~s}$ \\
\hline EP4 (PTGER4) & NM_00958.2 & $\begin{array}{l}\text { F: ACTGAGACCGGCTTTGAGAA } \\
\text { R: CCGGGAGTGGACATGATAGT }\end{array}$ & $\begin{array}{l}\text { bp } 407-426 \\
\text { bp } 606-587\end{array}$ & 200 & $100 \mathrm{ng}$ & $59^{\circ} \mathrm{C} / 45 \mathrm{~s}$ \\
\hline FP (PTGFR) & NM_000959.3 & $\begin{array}{l}\text { F: TGCAATGCAATCACAGGAAT } \\
\text { R: TGTTGGCCATTGTAACCAGA }\end{array}$ & $\begin{array}{l}\text { bp } 921-940 \\
\text { bp } 1080-1061\end{array}$ & 160 & $100 \mathrm{ng}$ & $59^{\circ} \mathrm{C} / 45 \mathrm{~s}$ \\
\hline Cyclophilin A & NM_021130.3 & $\begin{array}{l}\text { F: GTGGTGTTTGGCAAAGTGAA } \\
\text { R: TCGAGTTGTCCACAGTCAGC }\end{array}$ & $\begin{array}{l}\text { bp } 462-481 \\
\text { bp } 577-558\end{array}$ & 116 & $66 \mathrm{ng}$ & $56^{\circ} \mathrm{C} / 45 \mathrm{~s}$ \\
\hline
\end{tabular}


Table 3. Antibodies used in the study, their concentrations, buffers and incubation times.

\begin{tabular}{|c|c|c|c|c|c|c|c|c|}
\hline Protein & $\begin{array}{l}\text { Antigen } \\
\text { retrieval }\end{array}$ & Blocking & $\begin{array}{c}\text { Primary antibody } \\
\text { name and catalogue } \\
\text { number }\end{array}$ & $\begin{array}{c}\text { Primary } \\
\text { antibody type }\end{array}$ & $\begin{array}{l}\text { Primary } \\
\text { antibody } \\
\text { conc. }\end{array}$ & Secondary antibody & $\begin{array}{l}\text { Secondary } \\
\text { antibody } \\
\text { dilution }\end{array}$ & $\begin{array}{l}\text { Buffer for } \\
\text { antibody } \\
\text { dilution }\end{array}$ \\
\hline EP1 & Yes & $3 \%$ NDS & $\begin{array}{c}\text { Cayman Chemicals, } \\
101740\end{array}$ & $\begin{array}{l}\text { Polyclonal } \\
\text { Rabbit IgG }\end{array}$ & $6 \mathrm{ug} / \mathrm{ml}$ & $\begin{array}{l}\text { Biotinylated Donkey anti } \\
\text { rabbit IgG (1) }\end{array}$ & $1: 1000$ & $\begin{array}{l}\text { 3\% NDS in } \\
\text { PBS }\end{array}$ \\
\hline EP2 & Yes & $3 \%$ NDS & $\begin{array}{c}\text { Cayman Chemicals, } \\
101750\end{array}$ & $\begin{array}{l}\text { Polyclonal } \\
\text { Rabbit IgG }\end{array}$ & $2 \mathrm{ug} / \mathrm{ml}$ & $\begin{array}{l}\text { Biotinylated Donkey anti } \\
\text { rabbit IgG (1) }\end{array}$ & $1: 1000$ & $\begin{array}{l}\text { 3\% NDS in } \\
\text { PBS }\end{array}$ \\
\hline EP3 & Yes & $3 \% \mathrm{NDS}$ & $\begin{array}{c}\text { Cayman Chemicals, } \\
101760\end{array}$ & $\begin{array}{l}\text { Polyclonal } \\
\text { Rabbit IgG }\end{array}$ & $1.5 \mathrm{ug} / \mathrm{ml}$ & $\begin{array}{l}\text { Biotinylated Donkey anti } \\
\text { rabbit IgG (1) }\end{array}$ & $1: 1000$ & $\begin{array}{l}\text { 3\% NDS in } \\
\text { PBS }\end{array}$ \\
\hline EP4 & Yes & $3 \% \mathrm{NDS}$ & $\begin{array}{c}\text { Cayman Chemicals, } \\
101775\end{array}$ & $\begin{array}{l}\text { Polyclonal } \\
\text { Rabbit IgG }\end{array}$ & $5 \mathrm{ug} / \mathrm{ml}$ & $\begin{array}{l}\text { Biotinylated Donkey anti } \\
\text { rabbit IgG (1) }\end{array}$ & $1: 1000$ & $\begin{array}{l}3 \% \text { NDS in } \\
\text { PBS }\end{array}$ \\
\hline FP & Yes & $3 \%$ NDS & $\begin{array}{c}\text { Cayman Chemicals, } \\
101802\end{array}$ & $\begin{array}{l}\text { Polyclonal } \\
\text { Rabbit IgG }\end{array}$ & $10 \mathrm{ug} / \mathrm{ml}$ & $\begin{array}{l}\text { Biotinylated Donkey anti } \\
\text { rabbit IgG (1) }\end{array}$ & $1: 1000$ & $\begin{array}{l}3 \% \text { NDS in } \\
\text { PBS }\end{array}$ \\
\hline CTGF & Yes & $\begin{array}{l}10 \% \text { NSS } \\
\text { with } 0.1 \% \\
\text { BSA }\end{array}$ & $\begin{array}{l}\text { Acris Antibodies, } \\
\text { BM4099 }\end{array}$ & $\begin{array}{l}\text { Monoclonal } \\
\text { Mouse IgM }\end{array}$ & $13.3 \mathrm{ug} / \mathrm{ml}$ & $\begin{array}{l}\text { Biotinylated Rabbit anti } \\
\text { Mouse IgG (2) }\end{array}$ & $1: 400$ & $\begin{array}{l}\text { TBS with } \\
0.1 \% \text { BSA }\end{array}$ \\
\hline Cal B & No & $1.5 \%$ NHS & $\begin{array}{c}\text { BMA Biomedicals, T } \\
1028\end{array}$ & $\begin{array}{l}\text { Monoclonal } \\
\text { Mouse IgG }\end{array}$ & $0.2 \mathrm{ug} / \mathrm{ml}$ & $\begin{array}{l}\text { Biotinylated Horse anti } \\
\text { Mouse IgG (3) }\end{array}$ & $1: 200$ & $\begin{array}{l}1.5 \% \text { NHS in } \\
\text { PBS }\end{array}$ \\
\hline ALOX15 & Yes & $1.5 \%$ NHS & $\begin{array}{c}\text { Abnova, } \\
\text { H00000246-M04 }\end{array}$ & $\begin{array}{l}\text { Monoclonal } \\
\text { Mouse IgG }\end{array}$ & $2.5 \mathrm{ug} / \mathrm{ml}$ & $\begin{array}{l}\text { Biotinylated Horse anti } \\
\text { Mouse IgG (3) }\end{array}$ & $1: 200$ & $\begin{array}{l}1.5 \% \text { NHS in } \\
\text { PBS }\end{array}$ \\
\hline Furin & Yes & $1.5 \%$ NHS & $\begin{array}{l}\text { R\&D Systems, } \\
\text { MAB15031 }\end{array}$ & $\begin{array}{l}\text { Monoclonal } \\
\text { Mouse IgG }\end{array}$ & $10 \mathrm{ug} / \mathrm{ml}$ & $\begin{array}{l}\text { Biotinylated Horse anti } \\
\text { Mouse IgG (3) }\end{array}$ & $1: 200$ & $\begin{array}{l}1.5 \% \text { NHS in } \\
\text { PBS }\end{array}$ \\
\hline
\end{tabular}

1: Santa Cruz Biotechnology Inc. Cat no. SC-2089; 2: Dako Cytomation. Cat no. E0464; 3: Vector laboratories. Cat no BA-2000.

\subsection{Statistical Analysis}

Statistical analysis was performed by ANOVA on ranks (Kruskal-Wallis test) or one way ANOVA (for maternal age), if not otherwise stated, and significances were evaluated by Dunn's test. Values were considered significantly different when $P<0.05$.

\section{RESULTS}

\subsection{Clinical Characteristics of Patients}

Maternal age, BMI or birth weight did not show any differences between the TP and PP groups, but gestational age was lower in the TP than in the PP group (Table 1). This difference was expected since the TP group consists of women having planned caesarean sections at term, normally seven to ten days before the estimated date of delivery according to clinical guidelines and routine ultrasound dating in the second trimester. Since hysterectomies are rarely performed in younger patients, women in the NP group were older than the women in the TP and PP groups.

\subsection{Immunohistochemical Localization and mRNA Expression of EPs and FP}

Immunohistochemical analyses show the presence of EP and FP receptors and all the examined stromal factors in the cervix. Their expression pattern and staining intensity vary in different cell types and between study groups.
Immunohistochemical scoring was performed for squamous epithelium (SQ), glandular epithelium (GE), smooth muscle cells of arterial walls (smc), endothelium, leukocytes and stroma. Stroma consists of fibroblasts, smooth muscle cells, elastic and connective tissue. Representative images of the immunohistochemistry results are shown in Figure 1 for the PG receptors and in Figure 2 for the stromal factors. The representative immunohistochemical images shown in Figures $\mathbf{1}$ and $\mathbf{2}$ focuses on the regions displaying changes in expression as determined by the manual scoring as shown in Figures 3 and 4 respectively.

EP1 mRNA levels were very low, close to detection limit, and hence could not be reliably quantified. The immunoreactivity for EP1 was moderate to high in SQ, low to strong in endothelium, and low to moderate in smc of arterial walls, GE and stroma (Figures 1(a)-(d)). EP1 scores did not show any differences between the study groups (Figure 3, top panel).

The EP2 mRNA level was increased in the PP group as compared to the TP group (Figure 5, top panel). EP2 immunostaining was low to moderate in stroma and GE and low or absent in smc, SQ and endothelium (Figures 1(e)-(h)). Immunoreactivity for EP2 in stroma was significantly higher in the TP group than in the NP group (Figures 1 and 3, second panel from top).

There was no difference in EP3 mRNA expression between the groups (Figure 5, second panel from the top). EP3 immunoreactivity was moderate to high in 


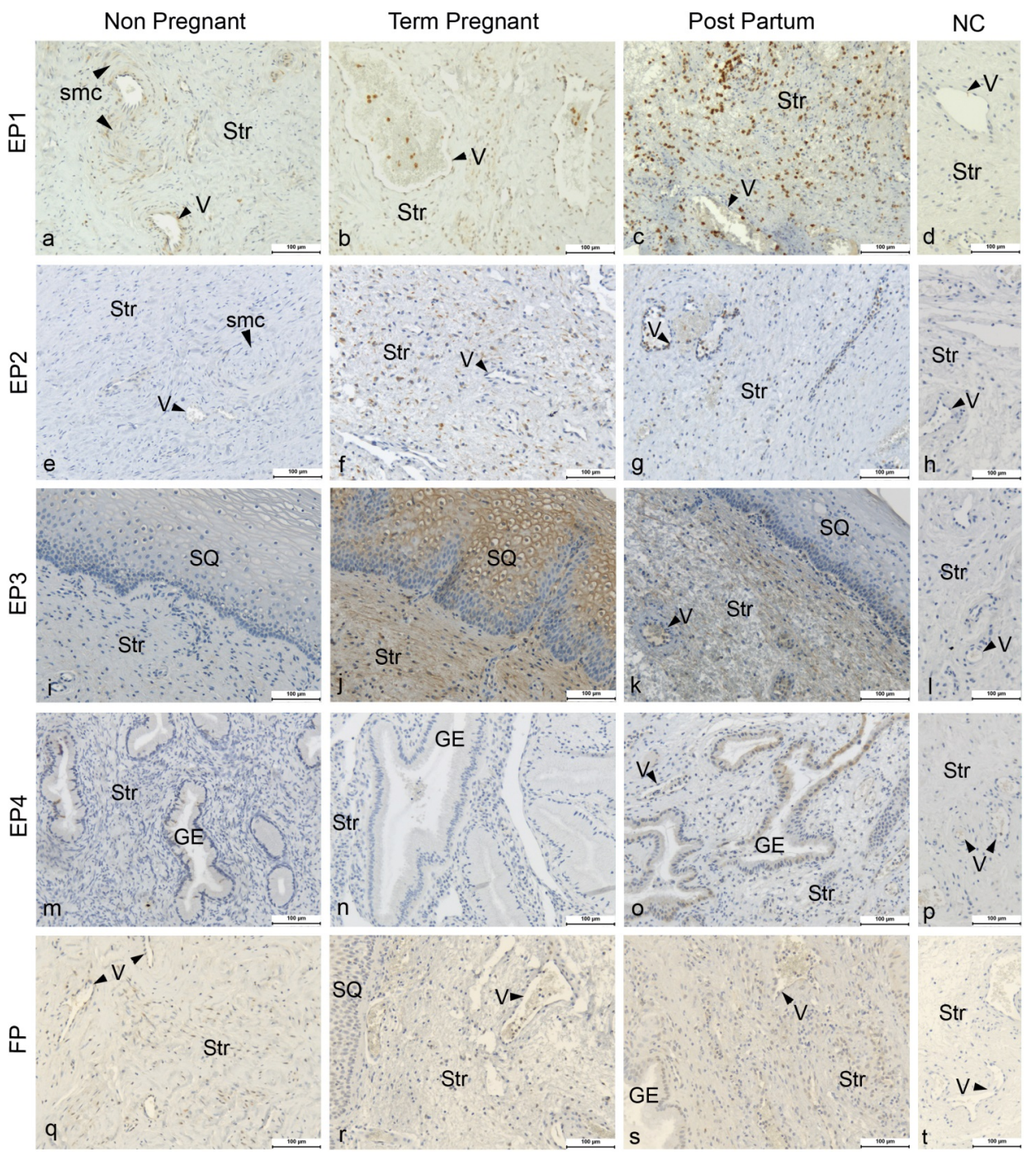

Figure 1. Figure showing the immunohistochemical images of cervical tissue from non-pregnant (Column 1), term-pregnant (Column 2) and post-partum (Column 3) women. Cervical sections were stained for EP1 (a)-(c), EP2 (e)-(g), EP3 (i)-(k), EP4 (m)-(o) and FP (q)-(s) along with their respective negative controls (Column 4 ) in the same row. Str: Stroma, GE: Glandular epithelium, V: Veins (arrow head indicating the endothelium), SQ: squamous epithelium, and smc: Smooth muscles in arterial walls. Magnification $\times 200$, Scale Bar- $100 \mu \mathrm{m}$.

stroma, moderate in endothelium, low in GE and low to moderate in SQ and low to strong in smc (Figures 1(i)-(l)). The immunostaining was higher in the SQ of the TP group as compared to the NP group (Figure 3, third panel from top).

The EP4 mRNA level exhibited a large variation in the NP group and was lower in the TP group as compared to NP group (Figure 5, second panel from the bottom). EP4 protein was absent or faintly expressed in stroma, smc and endothelium, low to moderate in GE and low to strong in SQ (Figures 1(m)-(p)). Immunostaining was mostly below detection limit in the TP group, although faintly present in SQ and endothelium (Figure 1(n)). There was higher immunostaining in GE of the PP group as compared to the TP group (Figures 1(m)-(o); Figure 3, second panel from bottom).

FP mRNA expression did not show any differences between the groups (Figure 5, bottom panel). Immunostaining of FP was low to moderate in stroma, endothelium and GE, while it was low to strong in smc and $\mathrm{SQ}$, no differences were found between groups (Figures 1(q)-(t); Figure 3, bottom panel).

\subsection{Immunohistochemical Localization of Stromal Factors}

CTGF immunostaining was moderate to strong in stroma, moderate in SQ, low to strong in smc, below detection limit in GE and low to moderate in endothelium (Figures 

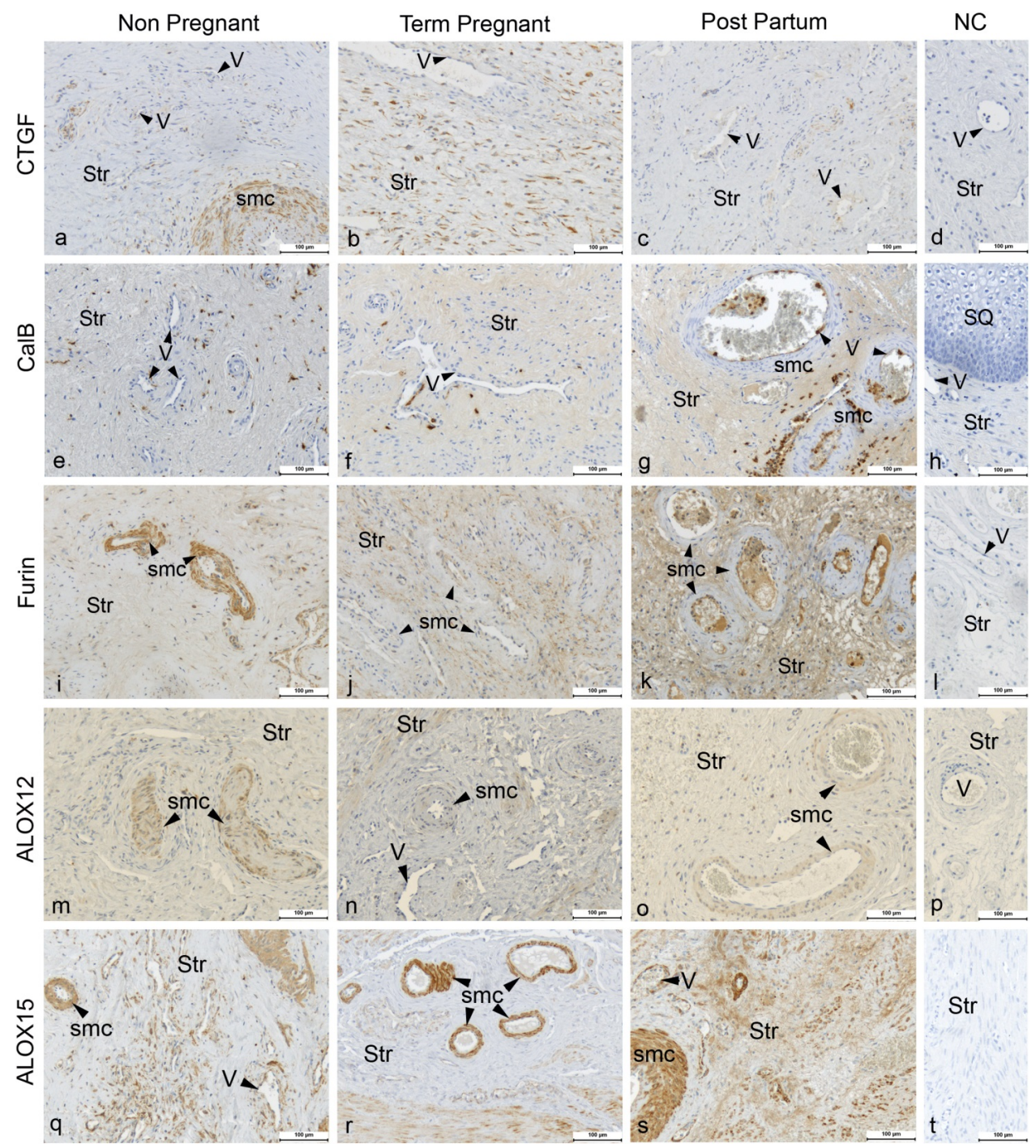

Figure 2. Figure showing the immunohistochemical images of cervical tissue from non-pregnant (Column 1), term-pregnant (Column 2) and post-partum (Column 3) women. Cervical sections were stained for CTGF (a)-(c), CalB (e)-(g), Furin (i)-(k), ALOX12 (m)-(o) and ALOX15 (q)-(s) along with their respective negative controls (Column 4) in the same row. Str: Stroma, GE: Glandular epithelium, V: Veins (arrow head indicating the endothelium), and smc: Smooth muscles in arterial walls. Magnification $\times 200$, Scale Bar- $100 \mu \mathrm{m}$.

2(a)-(d)). The immunostaining in the endothelium was lower in the TP and PP groups as compared to the NP group (Figure 4, top panel).

Calgranulin B immunostaining was moderate in stroma, below detection limit in GE, faint or below detection limit in smc, strong in SQ and low in endothelium (Figures 2(e)-(h)). In the endothelium calgranulin B immunostaining was higher in the PP as compared to NP group (Figure 4, second panel from the top).

Immunostaining of furin was moderate to strong in stroma and smc, low to moderate in SQ, moderate in endothelium and low in GE (Figures 2(i)-(I)). The immunoreactivity of furin in smc was lower in the TP group, with a similar trend in PP, as compared to the NP group
(Figures 2(i)-(k); Figure 4, third panel from the top).

ALOX12 immunostaining was low to moderate in stroma, smc, endothelium and GE, and low to high in SQ (Figures 2(m)-(p)). The immunostaining in the smc was lower in the TP group as compared to the NP group (Figures 2(m)-(o); Figure 4, second panel from bottom). A strong immunostaining of ALOX15 was found in stroma, smc and endothelium, whereas it was absent in GE and low in SQ, no differences between groups were found (Figures 2(q)-(t); Figure 4, bottom panel).

Manual scoring of immunostaining in leukocytes, as recognized by morphology within the cervical tissue, showed a relation to the amount of leukocytes (data not shown). Consequently, the immunostaining results mimic 


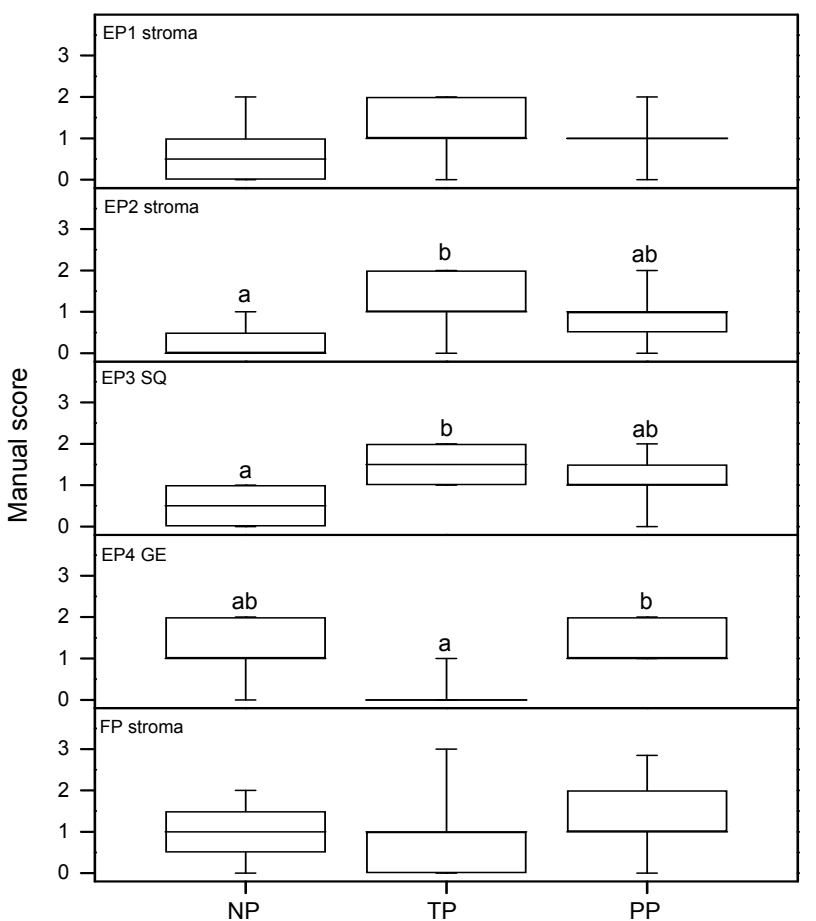

Figure 3. Results as assessed by manual scoring from immunohistochemistry images. From top to bottom: EP1 stroma; EP2 stroma; EP3 squamous epithelium; EP4 glandular epithelium and FP stroma. The $n$ values are $\mathrm{NP}=8 ; \mathrm{TP}=9$ and $\mathrm{PP}=$ 13 in all assays but EP2 where the PP group included 12 patients.

the amount of leukocyte influx. The immunostaining of EP1, EP2 and EP3 was increased in the PP group as compared to the NP group. For EP1 and EP2 in the PP group there was also a significant difference compared to the TP group (data not shown). EP4 immunostaining was sparsely observed in leukocytes. There was no significant difference found in FP immunoreactivity (data not shown). Also some of the stromal factors co-varied with leukocyte number (data not shown). Calgranulin B exhibited higher immunoreactivity in the PP group as compared to NP and TP groups. Furin showed increased immunoreactivity in the PP group as compared to the NP group. CTGF, ALOX12 and ALOX15 displayed no differences in leukocyte immunoreactivity between the groups (data not shown).

\section{DISCUSSION}

Our study shows the presence of PG receptors EP1-4 and FP in the human cervix. Their levels varied between the non-pregnant, pregnant and post-partum state and in different cervical cell types. Recent publications report that different PG receptor subtypes are present in different cell types of the rodent and human uterus [22,24].

Our data shows that EP2 and EP4 mRNA levels are at their lowest in the TP group. Thus, expressions of both

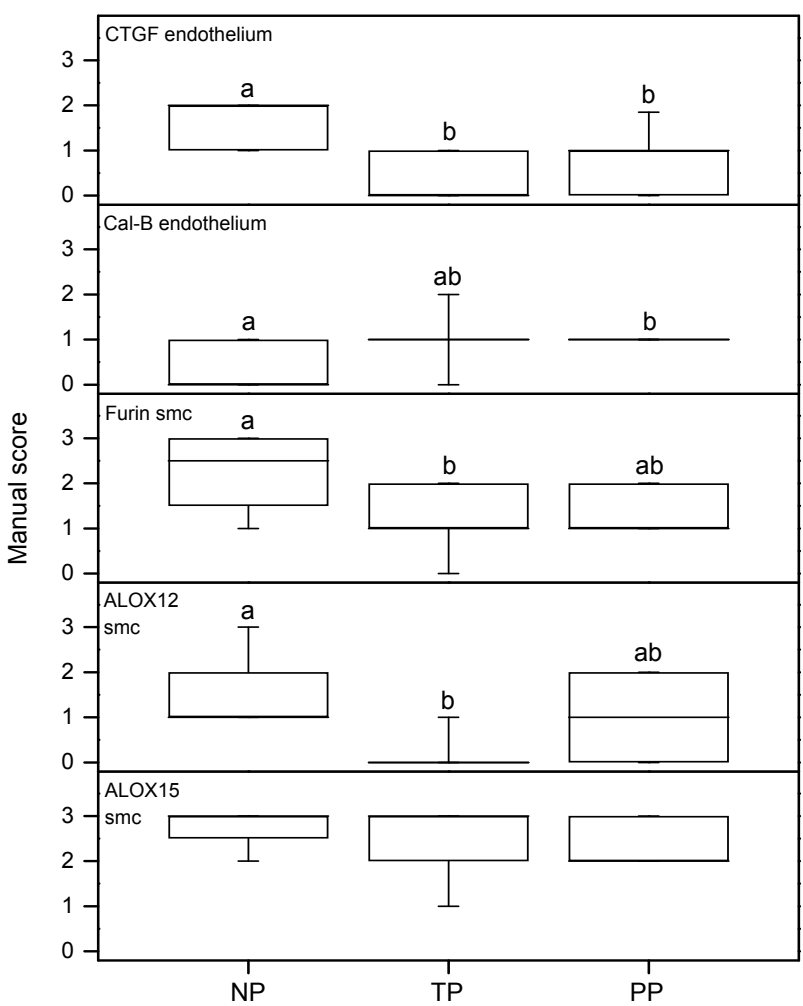

Figure 4. Results as assessed by manual scoring from immunohistochemistry images. From top to bottom: CTGF endothelium; Calgranulin B endothelium; Furin smooth muscle cells (smc); ALOX12 smc and ALOX15 smc. The $\mathrm{n}$ values are $\mathrm{NP}=$ $8 ; \mathrm{TP}=9$ and $\mathrm{PP}=13$ in all assays.

smooth muscle relaxing EPs are at their lowest levels in pregnancy before the final ripening has started. In endometrium, the level of EP2 mRNA is higher in the midsecretory stage, when the estrogen and progesterone levels are both high, as compared to the other phases during the menstrual cycle [24]. This is in agreement with our finding, since the estrogen and progesterone levels in the PP group is higher than in TP and NP groups $[25,26]$. The EP4 mRNA level was lower in the TP group as compared to the NP group, and EP4 protein showed less immunostaining in GE of the TP group as compared to the PP, with a similar trend also towards the NP group. Thus, expression of the EP4 was lowest in the term pregnant group. The low level in the TP group indicates that before final ripening/active labor, the expression of EP4, as well as EP2, is down regulated. In human endometrium the EP4 expression is lower in the first half of the menstrual cycle, when the estrogen level is high and progesterone low, as compared to the mid secretory stage when progesterone is at its highest level [24].

Earlier studies in goat and sheep suggested a possible relaxatory role of EP2 and EP4 in cervix based on their expression [8,27]. In the present study, EP2 mRNA was higher at the time of parturition as compared to the TP 


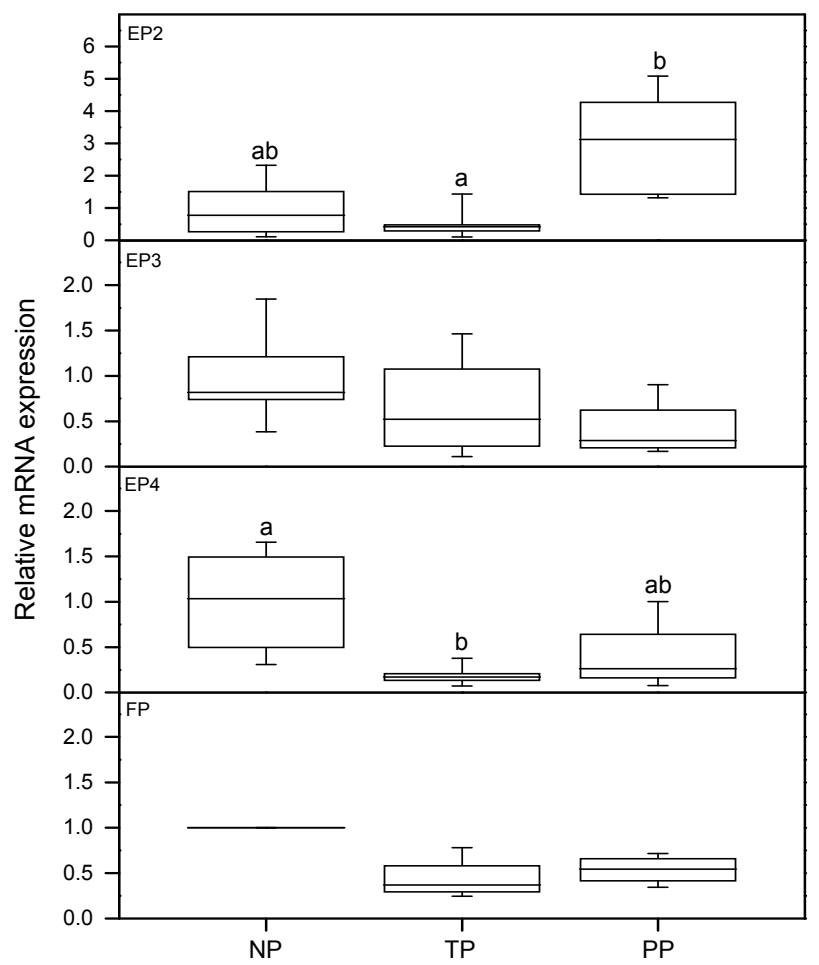

Figure 5. The mRNA levels of prostaglandin receptors EP2-4 and FP, as assessed by real-time PCR. The $\mathrm{n}$ values are $\mathrm{NP}=5$; $\mathrm{TP}=11$ and $\mathrm{PP}=5$ in all assays but $\mathrm{EP} 4$ where $\mathrm{NP}=3 ; \mathrm{PP}=4$, and in FP where $\mathrm{NP}=1 ; \mathrm{PP}=4$ due to the limited amount of RNA available. The FP mRNA level of the single patient is included as a reference value. The TP and PP groups were evaluated using Mann-Whitney's test, no statistical difference was found between the two groups.

group. EP2 mediates relaxation, so a higher level in the PP group seems appropriate. Since the amount of smooth muscles in cervix is relatively small, cervical ripening cannot be solely explained by the relaxation of smooth muscles due to the action of $\mathrm{PGE}_{2}$. It is known that $\mathrm{PGE}_{2}$ increases the concentration of glycosaminoglycan and the activity of elastin in cervix contributing to cervical ripening [28]. Further, it has been suggested that $\mathrm{PGE}_{2}$ regulates the synthesis of hyaluronan-like glycosaminoglycan [27] which has been shown to induce cervical ripening by remodeling the extracellular matrix via the dispersion and separation of collagen bundles [29]. Our earlier studies have shown that MMPs are vital for cervical ripening $[21,30]$. In endometrial stromal cells, inhibition of EP2 and EP4 suppress the expression and activities of several MMPs [31]. However, the stromal EP2 expression is high in the TP group when compared to the NP group suggesting that higher expression of EP2 may increase the effect of MMPs in stroma, which are important for cervical ripening and remodeling. Thus, the relaxatory action by smooth muscles (in stroma and arterial walls) along with the action of collagenases and other proteases could contribute to cervical ripening.
Most of the women in the PP group received oxytocin for labor augmentation during the active phase, but none in the TP or NP groups. It is possible that the expression of EP2 mRNA could be influenced by oxytocin administration; however no supporting literature is available. Further, we found no difference in post-term women, where oxytocin was given to women in all groups compared (unpublished observations, Roos et al., in preparation).

The expression of the contraction inducing PG receptors, i.e. EP1, EP3 and FP, was either low or unchanged between the study groups. EP1 mRNA expression was present in very low amounts. However, the protein was detected by immunohistochemistry, but no differences between any of the groups were found. The low expression of EP1 mRNA in the cervix is in agreement with results from a study on mice [32]. In our previous study on rat uterus, EP1 mRNA was found to be down regulated by estradiol [22]. Nevertheless, in recent studies on human endometrium and myometrium both EP1 mRNA and protein were found $[24,33,34]$. These observations show that there are great variations in the expression patterns between tissues (i.e. endometrium/myometrium vs. cervix) and under different hormonal influences (menstrual cycle vs. pregnancy). Further, the discrepancy between the mRNA and protein levels could also be issues related to EP1 mRNA stability. The EP3 protein level was higher in the SQ of the TP group as compared to NP. EP3 localization in SQ has been reported in rats [35] but the exact role of EP3 in epithelial cells is not known. The absence of regulation of the contractile PG receptors mRNA and protein levels in most of the cell types suggest that they may not play any active role in the cervical ripening process. Similar observations and conclusions have been derived in rats [35].

CTGF staining was evaluated since this growth factor has been found to be regulated by ovarian steroid hormones and implicated in ECM remodeling in animal models [36]. A significant decrease of CTGF in the endothelial cells in cervices from pregnant women was found, when compared to non-pregnant women. Thus, CTGF expression in endothelial cells could also be regulated by ovarian steroids in human cervix. Further, the expression of CTGF in endothelial cells is regulated by shear stress induced by blood flow [37]. It is likely that the blood flow pattern could be different because of the tissue remodeling in cervices from pregnant and postpartum women when compared to the NP group. In cervical tissue and mucosa, increased calgranulin B expression has been found during preterm labor and at term [14]. The spatial localization and cellular properties of calgranulin B combined with its dramatic increase in cervix and myometrium of women in labor, suggest that this protein may be important in the initiation or propagation of human labor [14]. The specific role of cal- 
granulin $\mathrm{B}$ in endothelium has been attributed to inflammation [38]. We found that calgranulin B immunostaining was increased in the endothelium of women in the PP group as compared to those in the NP group, suggesting its inflammatory role also in cervix.

Furin is known to activate several of the MMPs [39] which are important factors in the ECM remodeling of the cervix prior to parturition [21]. In smooth muscle cells around the vessels furin immunostaining was found lower in the TP group as compared to NP, suggesting involvement in vascular remodeling [40]. Indeed, furin has been shown to enhance the survival of vascular smooth muscle cells [41].

Lipoxygenases participate in the metabolism of the polyunsaturated fatty acids and catalyzing their oxidation to a variety of eicosanoids, which as the secondary signal transducers have a major impact on human homeostasis [42]. ALOX12 has been described in human cervix with no difference in expression between proliferative and secretory phase of the menstrual cycle [17]. Still, the lower levels of ALOX12 found in samples from postmenopausal women suggest that gonadal steroid hormones could influence its expression [17]. In baboon uterus during pregnancy and labor, ALOX12 tended to be less expressed in the cervical part from animals in labor [18]. The TP group shows a down-regulation which also implies a possible steroid hormone regulation of ALOX12 in human cervix. Recent studies show that ALOX12 is involved in vascular aging and vascular smooth muscle survival $[43,44]$. The downregulation of ALOX12 in vascular smooth muscle cells in TP cervix could suggest its role in vascular smooth muscle remodeling prior to cervical ripening. ALOX15 is present and functional in myometrium from pregnant women, and the expression was lower in term and during labor [19]. In the study on baboon uterus, no difference was found in the cervix of animals in different stages of labor [18], which is in agreement with our results.

Obtaining human cervical tissues is difficult and the limited size of the collected cervical tissue did not allow us to perform real-time PCR for the stromal factors. It would have been desirable to perform Western blots as well, to enable us to compare protein and mRNA levels, since the PCR results are obtained from a homogenate of the cervical tissue. We chose to perform immunohistochemical analyses as that offers the possibility to detect the cell type specific protein expression, even if it cannot give the quantifiable data similar to Western blots.

In conclusion, our study shows distinct changes in the expression of EPs and stromal factors in cervices from women in the NP, PP and TP groups. The low mRNA levels of EP2 and EP4 in smooth muscles of the TP group, along with the changes in the relative protein levels of tissue remodeling stromal factors like CTGF, calgranulin $\mathrm{B}$, furin and ALOX12 could contribute to cer- vical ripening. The relaxatory action by smooth muscles together with the timed action of tissue remodeling enzymes could lead to the cervical ripening. Further studies on the mechanistic aspects of regulation are warranted to identify the exact molecular mechanism of cervical ripening and PG signaling.

\section{ACKNOWLEDGEMENTS}

We are grateful for the technical assistance by Lavanya Ramimeni. This study received financial support from The Swedish Research Council (projects 20137 (LS) 14612 (GEO)) and Karolinska Institutet. C.S. Blesson had a post doc scholarship from the Swedish Institute. Financial support was also provided through the regional agreement on medical training and clinical research (ALF) between Stockholm County Council and Karolinska Institutet and from the Board of Post Graduate Education at Karolinska Institutet, Stockholm, Sweden (KIDfunding) (NR).

\section{REFERENCES}

[1] Hertelendy, F. and Zakar, T. (2004) Prostaglandins and the myometrium and cervix. Prostaglandins, Leukotrienes and Essential Fatty Acids, 70, 207-222. http://dx.doi.org/10.1016/j.plefa.2003.04.009

[2] Osman, I., Young, A., Ledingham, M.A., Thomson, A.J., Jordan, F., Greer, I.A. and Norman, J.E. (2003) Leukocyte density and pro-inflammatory cytokine expression in human fetal membranes, decidua, cervix and myometrium before and during labour at term. Molecular Human Reproduction, 9, 41-45. http://dx.doi.org/10.1093/molehr/gag001

[3] Sennstrom, M.B., Ekman, G., Westergren-Thorsson, G., Malmstrom, A., Bystrom, B., Endresen, U., Mlambo, N., Norman, M., Stabi, B. and Brauner, A. (2000) Human cervical ripening, an inflammatory process mediated by cytokines. Molecular Human Reproduction, 6, 375-381. http://dx.doi.org/10.1093/molehr/6.4.375

[4] Ekman, G., Malmstrom, A., Uldbjerg, N. and Ulmsten, U. (1986) Cervical collagen: An important regulator of cervical function in term labor. Obstetrics and Gynecology, 67, 633-636.

http://dx.doi.org/10.1097/00006250-198605000-00006

[5] Bygdeman, M., Bremme, K., Christensen, N., Lundstrom, V. and Green, K. (1980) A comparison of two stable prostaglandin $\mathrm{E}$ analogues for termination of early pregnancy and for cervical dilatation. Contraception, 22, 471-483. http://dx.doi.org/10.1016/0010-7824(80)90100-6

[6] Woodward, D.F., Jones, R.L. and Narumiya, S. (2011) International union of basic and clinical pharmacology. LXXXIII: Classification of prostanoid receptors, updating 15 years of progress. Pharmacological Reviews, 63, 471-538. http://dx.doi.org/10.1124/pr.110.003517

[7] Breyer, R.M., Bagdassarian, C.K., Myers, S.A. and Breyer, M.D. (2001) Prostanoid receptors: Subtypes and signaling. Annual Reviews of Pharmacology and Toxicology, 41, 661-690.

http://dx.doi.org/10.1146/annurev.pharmtox.41.1.661 
[8] Gu, G., Gao, Q., Yuan, X., Huang, L. and Ge, L. (2012) Immunolocalization of adipocytes and prostaglandin E2 and its four receptor proteins EP1, EP2, EP3, and EP4 in the caprine cervix during spontaneous term labor. Biology of Reproduction, 86, 1-10. http://dx.doi.org/10.1095/biolreprod.111.096040

[9] Yellon, S.M., Ebner, C.A. and Sugimoto, Y. (2008) Parturition and recruitment of macrophages in cervix of mice lacking the prostaglandin F receptor. Biology of Reproduction, 78, 438-444. http://dx.doi.org/10.1095/biolreprod.107.063404

[10] Schmitz, T., Levine, B.A. and Nathanielsz, P.W. (2006) Localization and steroid regulation of prostaglandin E2 receptor protein expression in ovine cervix. Reproduction, 131, 743-750. http://dx.doi.org/10.1530/rep.1.00767

[11] Hassan, S.S., Romero, R., Tarca, A.L., Nhan-Chang, C.L., Vaisbuch, E., Erez, O., Mittal, P., Kusanovic, J.P., Mazaki-Tovi, S., Yeo, L., et al. (2009) The transcriptome of cervical ripening in human pregnancy before the onset of labor at term: Identification of novel molecular functions involved in this process. The Journal of Maternal-Fetal \&Neonatal Medicine, 22, 1183-1193. http://dx.doi.org/10.3109/14767050903353216

[12] Ryckman, C., Vandal, K., Rouleau, P., Talbot, M. and Tessier, P.A. (2003) Proinflammatory activities of S100: Proteins S100A8, S100A9, and S100A8/A9 induce neutrophil chemotaxis and adhesion. Journal of Immunology, 170, 3233-3242.

[13] Greenlee, K.J., Corry, D.B., Engler, D.A., Matsunami, R.K., Tessier, P., Cook, R.G., Werb, Z. and Kheradmand, F. (2006) Proteomic identification of in vivo substrates for matrix metalloproteinases 2 and 9 reveals a mechanism for resolution of inflammation. Journal of Immunology, 177, 7312-7321.

[14] Havelock, J.C., Keller, P., Muleba, N., Mayhew, B.A., Casey, B.M., Rainey, W.E. and Word, R.A. (2005) Human myometrial gene expression before and during parturition. Biology of Reproduction, 72, 707-719. http://dx.doi.org/10.1095/biolreprod.104.032979

[15] Verma, R.P. and Hansch, C. (2007) Matrix metalloproteinases (MMPs): Chemical-biological functions and (Q) SARs. Bioorganic Medicinal Chemistry, 15, 2223-2268. http://dx.doi.org/10.1016/i.bmc.2007.01.011

[16] Uderhardt, S. and Kronke, G. (2012) 12/15-Lipoxygenase during the regulation of inflammation, immunity, and self-tolerance. Journal of Molecular Medicine, 90, 12471256. http://dx.doi.org/10.1007/s00109-012-0954-4

[17] Flatman, S., Morgan, A., McDonald-Gibson, R.G., Davey, A., Jonas, G.E. and Slater, T.F. (1988) 12-lipoxygenase activity in human uterine cervix. Prostaglandins, Leukotrienes, and Essential Fatty Acids, 32, 87-94. http://dx.doi.org/10.1016/0952-3278(88)90101-9

[18] Smith, G.C., Wu, W.X. and Nathanielsz, P.W. (2001) Lipoxygenase gene expression in baboon intrauterine tissues in late pregnancy and parturition. Molecular Human Reproduction, 7, 587-594. http://dx.doi.org/10.1093/molehr/7.6.587

[19] Lei, Z.M. and Rao, C.V. (1992) The expression of 15lipoxygenase gene and the presence of functional enzyme in cytoplasm and nuclei of pregnancy human myometria. Endocrinology, 130, 861-870.

http://dx.doi.org/10.1210/en.130.2.861

[20] Wen, Y., Gu, J., Chakrabarti, S.K., Aylor, K., Marshall, J., Takahashi, Y., Yoshimoto, T. and Nadler, J.L. (2007) The role of 12/15-lipoxygenase in the expression of interleukin-6 and tumor necrosis factor-alpha in macrophages. Endocrinology, 148, 1313-1322. http://dx.doi.org/10.1210/en.2006-0665

[21] Stygar, D., Wang, H., Vladic, Y.S., Ekman, G., Eriksson, H. and Sahlin, L. (2002) Increased level of matrix metalloproteinases 2 and 9 in the ripening process of the human cervix. Biology of Reproduction, 67, 889-894. http://dx.doi.org/10.1095/biolreprod.102.005116

[22] Blesson, C.S., Buttner, E., Masironi, B. and Sahlin, L. (2012) Prostaglandin receptors EP and FP are regulated by estradiol and progesterone in the uterus of ovariectomized rats. Reproductive Biology and Endocrinology, 10, 3. http://dx.doi.org/10.1186/1477-7827-10-3

[23] Altmae, S., Salumets, A., Bjuresten, K., Kallak, T.K., Wanggren, K., Landgren, B.M., Hovatta, O. and Stavreus-Evers, A. (2011) Tissue factor and tissue factor pathway inhibitors TFPI and TFPI2 in human secretory endometrium-Possible link to female infertility. Reproductive Sciences, 18, 666-678.

[24] Catalano, R.D., Wilson, M.R., Boddy, S.C. and Jabbour, H.N. (2011) Comprehensive expression analysis of prostanoid enzymes and receptors in the human endometrium across the menstrual cycle. Molecular Human Reproduction, 17, 182-192.

http://dx.doi.org/10.1093/molehr/gaq094

[25] Stjernholm, Y., Sahlin, L., Akerberg, S., Elinder, A., Eriksson, H.A., Malmstrom, A. and Ekman, G. (1996) Cervical ripening in humans: Potential roles of estrogen, progesterone, and insulin-like growth factor-I. American Journal of Obstetics and Gynecolology, 174, 1065-1071. http://dx.doi.org/10.1016/S0002-9378(96)70352-6

[26] Stjernholm, Y., Sahlin, L., Malmstrom, A., Barchan, K., Eriksson, H.A. and Ekman, G. (1997) Potential roles for gonadal steroids and insulin-like growth factor I during final cervical ripening. Obstetrics and Gynecology, 90, 375-380. http://dx.doi.org/10.1016/S0029-7844(97)00245-7

[27] Kershaw-Young, C.M., Khalid, M., McGowan, M.R., Pitsillides, A.A. and Scaramuzzi, R.J. (2009) The mRNA expression of prostaglandin E receptors EP2 and EP4 and the changes in glycosaminoglycans in the sheep cervix during the estrous cycle. Theriogenology, 72, 251-261. http://dx.doi.org/10.1016/j.theriogenology.2009.02.018

[28] Rath, W., Osmers, R., Adelmann-Grill, B.C., Stuhlsatz, H.W., Szevereny, M. and Kuhn, W. (1993) Biochemical changes in human cervical connective tissue after intracervical application of prostaglandin E2. Prostaglandins, 45, 375-384.

http://dx.doi.org/10.1016/0090-6980(93)90114-M

[29] El Maradny, E., Kanayama, N., Kobayashi, H., Hossain, B., Khatun, S., Liping, S., Kobayashi, T. and Terao, T. (1997) The role of hyaluronic acid as a mediator and regulator of cervical ripening. Human Reproduction, 12, 
1080-1088. http://dx.doi.org/10.1093/humrep/12.5.1080

[30] Sennstrom, M.B., Brauner, A., Bystrom, B., Malmstrom, A. and Ekman, G. (2003) Matrix metalloproteinase- 8 correlates with the cervical ripening process in humans. Acta Obstetricia et Gynecologica Scandinavica, 82, 904-911.

[31] Lee, J., Banu, S.K., Subbarao, T., Starzinski-Powitz, A. and Arosh, J.A. (2011) Selective inhibition of prostaglandin E2 receptors EP2 and EP4 inhibits invasion of human immortalized endometriotic epithelial and stromal cells through suppression of metalloproteinases. Molecular and Cellular Endocrinology, 332, 306-313. http://dx.doi.org/10.1016/j.mce.2010.11.022

[32] Sugimoto, Y. and Narumiya, S. (2007) Prostaglandin E receptors. Journal of Biological Chemistry, 282, 1161311617. http://dx.doi.org/10.1074/jbc.R600038200

[33] Astle, S., Thornton, S. and Slater, D.M. (2005) Identification and localization of prostaglandin E2 receptors in upper and lower segment human myometrium during pregnancy. Molecular Human Reproduction, 11, 279-287. http://dx.doi.org/10.1093/molehr/gah158

[34] Arulkumaran, S., Kandola, M.K., Hoffman, B., Hanyaloglu, A.C., Johnson, M.R. and Bennett, P.R. (2012) The roles of prostaglandin EP 1 and 3 receptors in the control of human myometrial contractility. Journal of Clinical Endocrinolology and Metababolism, 97, 489-498. http://dx.doi.org/10.1210/jc.2011-1991

[35] Hinton, A.C., Grigsby, P.L., Pitzer, B.A., Brockman, D.E., Ittenbach, R.F., Hinton, R.B. and Myatt, L. (2010) Hormonal regulation of prostaglandin E2 receptors: Localization and expression in rat cervical tissue. Reproductive Sciences, 17, 136-146.

[36] Rageh, M.A., Moussad, E.E., Wilson, A.K. and Brigstock, D.R. (2001) Steroidal regulation of connective tissue growth factor (CCN2; CTGF) synthesis in the mouse uterus. Molecular Pathology, 54, 338-346. http://dx.doi.org/10.1136/mp.54.5.338

[37] Cicha, I., Goppelt-Struebe, M., Yilmaz, A., Daniel, W.G. and Garlichs, C.D. (2008) Endothelial dysfunction and monocyte recruitment in cells exposed to non-uniform shear stress. Clinical Hemorheology and Microcirculation, 39, 113-119.

[38] Kannan, S. (2003) Inflammation: A novel mechanism for the transport of extracellular nucleotide-induced arachidonic acid by S100A8/A9 for transcellular metabolism. Cell Biology International, 27, 593-595. http://dx.doi.org/10.1016/S1065-6995(03)00082-9

[39] Ra, H.J. and Parks, W.C. (2007) Control of matrix metalloproteinase catalytic activity. Matrix Biology: Journal of the International Society for Matrix Biology, 26, 587596. http://dx.doi.org/10.1016/j.matbio.2007.07.001

[40] Stawowy, P. and Kappert, K. (2011) The molecular boilogy of furin-like proprotein convertases in vascular remodelling. Methods in Molecular Biology, 768, 191-206. http://dx.doi.org/10.1007/978-1-61779-204-5 9

[41] Urban, D., Lorenz, J., Meyborg, H., Ghosh, S., Kintscher, U., Kaufmann, J., Fleck, E., Kappert, K. and Stawowy, P. (2013) Proprotein convertase furin enhances survival and migration of vascular smooth muscle cells via processing of pro-nerve growth factor. Journal of Biochemistry, 153, 197-207. http://dx.doi.org/10.1093/jb/mvs137

[42] Skrzypczak-Jankun, E., Jankun, J. and Al-Senaidy, A. (2012) Human lipoxygenase: Developments in its structure, function, relevance to diseases and challenges in drug development. Current Medicinal Chemistry, 19, 5122-5127.

http://dx.doi.org/10.2174/092986712803530520

[43] Kim, H.Y., Jeong, D.W., Park, H.S., Lee, T.Y. and Kim, H.S. (2013) Comparison of 12-lipoxygenase expression in vascular smooth muscle cells from old normotensive Wistar-Kyoto rats with spontaneously hypertensive rats. Hypertension Research, 36, 65-73. http://dx.doi.org/10.1038/hr.2012.119

[44] Weisinger, G., Grafi-Cohen, M., Hirsh, M., Knoll, E., Sharon, O., Many, A., Limor, R. and Stern, N. (2013) 12SLipoxygenase is necessary for human vascular smooth muscle cell survival. Experimental Cell Research, 319, 1586-1593. http://dx.doi.org/10.1016/j.yexcr.2013.04.001 